\title{
Pelatihan Dzikir untuk Menurunkan Stres Akademik Siswa
}

\author{
Novia Rajianti ${ }^{1}$, Arih Merdekasari ${ }^{2}$
}

\author{
Prodi Pendidikan Agama Islam STIT Islamiyah Karya Pembangunan paron Ngawi \\ novia968@gmail.com ${ }^{1}$, arihatma01@gmail.com ${ }^{2}$
}

\begin{abstract}
Abstrak
Tingginya standar akademik yang diharapkan sekolah dan orangtua, banyaknya tugas serta ujian membuat siswa mengalami stres akademik. Ketidakmampuan siswa mengelola stres akademik menimbulkan dampak negatif pada fisik dan prestasi akademiknya. Dzikir merupakan salah satu bentuk ibadah dalam Islam yang digunakan dalam mengelola stres. Penelitian ini bertujuan meneliti pengaruh pelatihan dzikir terhadap penurunan stres akademik siswa. Subyek penelitian berjumlah 58 siswa berusia 12 hingga 15 tahun di kelas 7 dan 8 SMPN 2 Sine. Terdapat 27 siswa pada kelompok eksperimen, yaitu 13 laki-laki dan 14 perempuan. Sedangkan kelompok kontrol berjumlah 27 siswa, 11 laki-laki dan 16 perempuan. Pengukuran stres akademik menggunakan skala stres akademik. Rancangan penelitian ini adalah kuasi-eksperimen dengan desain pre-post control group design. Analisis data menggunakan tekhnik uji beda non parametrik mann-withney dengan melihat gained score, pre-test dan post-test. Uji Mann whitney gained Score Test Pre-test dan post-test kelompok eksperimen dan kelompok kontrol menunjukkan tidak adanya perbedaan stres akademik, dengan nilai $\mathrm{Z}=-1,222, \mathrm{p}=0,111(\mathrm{P}>0.50)$. Berdasarkan hasil analisa dapat disimpulkan bahwa pelatihan dzikir tidak berpengaruh secara signifikan pada penurunan stres akademik siswa.
\end{abstract}

Kata Kunci : mahasiswa, pelatihan zikir, stres akademik

\begin{abstract}
The high academic standards expected of schools and parents, the large number of assignments and examinations make students experiencing academic stress. The inability of students to manage academic stress has a negative impact on their physical and academic performance. Dhikr is a form of worship in Islam that used in managing stress. This study aims to examine the effect of dhikr training on reducing students' academic stress. The study subjects are 58 students aged 12 to 15 years in grades 7 and 8 of SMPN 2 Sine. There were 27 students in the experimental group and 27 students in the control group. Academic stress measurement uses an academic stress scale. The design of this study is a quasi-experimental design with pre-post control group design. The data analysis using difference test techniques of non-parametric mann-withney by looking at gained scores, pre-test and posttest. Mann whitney gained score Test Pre-test and post-test experimental and control groups showed no difference in academic stress, with a value of $\mathrm{Z}=-1.222, \mathrm{p}=0.111(\mathrm{P}>0.50)$. Based on the results of the analysis it can be concluded that the Dhikr training has no effect on reducing student academic stress.
\end{abstract}

Keywords: Student, Dhikr Training, Stress Academic

\section{PENDAHULUAN}

Beban materi pelajaran di sekolah semakin bertambah. Menghadapinya banyak pihak sekolah dan orang tua siswa memutuskan mengadakan program intensif atau bimbingan belajar agar siswa dapat mencapai target belajar yang telah ditentukan. Penerapan bimbingan belajar intensif memiliki sisi positif dan negatif. Sisi positifnya, siswa merasa terbantu dalam memahami materi yang dianggap sulit melalui tambahan jam belajar. Sedangkan sisi negatifnya, siswa merasakan kelelahan. Hal ini sesuai dengan temuan (Fischer dkk., 2008) bahwa remaja mengalami kelelahan dan kurang tidur yang salah satunya disebabkan oleh 
adaptasi terhadap jam sekolah.

Studi pada 742 remaja berusia 12 hingga 18 tahun yang bersekolah di sekolah menengah pertama, sekolah menengah atas dan sekolah menengah kejuruan di Yogyakarta dan Surabaya menunjukkan bahwa masalah sekolah masuk dalam kategori tiga besar masalah utama yang dialami remaja. (Liem, Budiman Onggowijoyo, Santoso, Kurniastuti, \& Yuniarti, 2013). Tuntutan akademik yang tinggi dan harapan orangtua terhadap keberhasilan siswa dapat menjadi penyebab stres yang dialami siswa (Lal, 2014). Adanya stres akademik berdampak negatif terhadap siswa. Kegiatan yang ditujukan untuk meningkatkan prestasi akademik dapat mengakibatkan hal sebaliknya, yaitu penurunan prestasi akademik.

Stress akademik berhubungan dengan berbagai aspek negatif dalam kehidupan remaja. kualitas tidur, kelelahan sekolah dan depresi menunjukkan bahwa stres akademik remaja berkorelasi negatif dengan kualitas tidur dan bahwa depresi dan kelelahan sekolah juga berkorelasi negatif dengan kualitas tidur (Yan, Rongmao, Su, \& Liu, 2018).

Stres akademik yang dialami siswa sekolah menengah dan tinggi menunjukkan berbagai dampak negatif. Indikator yang ditunjukkan adalah berkurangnya kualitas kesehatan dan produktivitas. Stres akademik berpengaruh pada kapasitas belajar, kinerja akademik, pendidikan, pencapaian pekerjaan, kualitas dan kuantitas tidur, kesehatan fisik dan kesehatan mental (Pascoe, Hetrick, \& Parker, 2019).

Berdasarkan kajian penelitian yang telah dilaksanakan sangat diperlukan upaya untuk membekali siswa mengelola stres akademiknya. Pengelolaan stres akademik saat ini telah dilakukan dengan berbagai macam pendekatan. Salah satunya pendekatan agama, Islam menyediakan obat bagi munculnya stres melalui berbagai bentuk ibadah. Diantaranya, sholat, doa dan zikir. Stress akan dapat dikelola dengan baik apabila pemeluk agama Islam menjalankan ibadahnya dengan baik (Yuwono, 2010).

Zikir merupakan ibadah yang banyak diteliti dalam pengelolaan stres. Pada konferensi Psikologi Islami di Surakarta dipaparkan bahwa dzikir dapat digunakan untuk menurunkan stress pada wanita single parent (Hamid, Anwar, \& Fasikhah, 2012) Penelitian lainnya menunjukkan pentingnya penambahan aspek spritual melalui zikir dalam perawatan kebidanan untuk wanita hamil. Terjadi penurunan stres dan gejala depresi yang signifikan pada wanita hamil yang menerima perawatan kebidanan disertai zikir spritual (Wahyuni, Anis, Soejoenoes, Putra, \& Syukur, 2018).

Temuan yang sama terdapat pada penelitian di Malaysia (Ali dkk., 2018) bahwa zikir dengan membaca surah Alfatihah dapat digunakan sebagai alternatif dalam mengatasi stress yang dialami individu. Keberhasilan ini karena dzikir mampu menstabilkan denyut jantung individu yang mengalami stress. Pada bidang pendidikan, penelitian dzikir juga dilakukan untuk menurunkan stres yang berkaitan dengan kesehatan mahasiswa melalui pengukuran DASS Questionnaire (Depression Anxiety Stress Scale). Studi pengaruh pelatihan dzikir terhadap penurunan stress dilakukan pada mahasiswa Magister Psikologi Profesi UII (Sucinindyasputeri, Mandala, Zaqiyatuddinni, \& Adityas, 2017). Sedangkan penelitian (Wahyu Rochdiat, Hestu, \& Lestiawati, 2019) dilaksanakan pada mahasiswa Ilmu Kesehatan Universitas Respati yogyakarta.

Analisa temuan penelitian menggambarkan belum adanya kajian khusus pada penelitian pengaruh pelatihan dzikir untuk menurunkan stres akademik. Selain itu subyek yang diteliti pada studi pelatihan dzikir dan stress hanya dilaksanakan pada kategori mahasiswa. Hal ini 
mengindikasikan pentingyan penelitian pengaruh pelatihan dzikir terhadap penurunan stres akademik siswa.

Penelitian ini merupakan penelitian kuasi eksperimen dengan model rancangan Pre-test Post-test Control Group Design, yaitu desain eksperimen yang dilakukan dengan pre-test sebelum pemberian perlakuan dan post-test sesudahnya, sekaligus ada kelompok perlakuan dan kontrol. Subyek penelitian berjumlah55 siswa. 28 siswa di kelompok eksperimen, yaitu 13 siswa laki-laki dan 15 siswa perempuan. Kelompok kontrol terdiri dari 27 siswa, yaitu 11 siswa laki-laki dan 16 siswa perempuan. Subyek penelitian adalah siswa yang berusia 12-15 tahun di kelas 7 dan kelas 8 SMPN 2 Sine Ngawi. Skala yang digunakan adalah skala stres akademik yang disusun berdasarkan respon terhadap stressor akademik meliputi ; ujian, menulis atau kecemasan berbicara didepan umum. Prokrastinasi serta standar akademik yang tinggi (Nist-Olejnik \& Holschuh, 2016).

Tabel 1. Contoh Item Skala Stress Akademik

\begin{tabular}{cll}
\hline Stressor & \multicolumn{1}{c}{ Respon } & \multicolumn{1}{c}{ Item } \\
\hline Ujian & Pikiran & Saya menganggap ujian itu sulit \\
& Perasaan & Saya merasa senang jika ada ujian. \\
& Perilaku & Saya memilih tidur daripada belajar untuk ujian \\
& Reaksi Fisik & Saya menjadi berkeringat ketika ada ujian mendadak \\
\hline
\end{tabular}

Skala ini berbentuk skala likert yang masing-masing aitem memiliki 5 alternatif jawaban, yaitu: sangat tidak setuju (STS), tidak setuju (TS), Netral (N), setuju (S) dan sangat setuju (SS). Skala stres akademik diujicobakan kepada 153 siswa kelas 7 dan 8 berusia 12-15 tahun di SMPN 2. Hasilnya terdapat 22 item dengan koefisien realibilitas $\alpha$ sebesar 0,841. Artinya, skala stres akademik memiliki tingkat kepercayaan sebesar $84,1 \%$, atau dengan kata lain jika dikenakan pada subjek yang sama dalam waktu yang berbeda 84,1\% akan memiliki hasil yang sama. Analisis data penelitian menggunakan teknik uji beda non parametrik Mann Whitney.

\section{HASIL}

Tabel 1 menunjukkan hasil uji Mann Whitney Gained Score pada kelompok eksperimen dan kelompok kontrol menunjukkan tidak adanya pengaruh pelatihan dzikir pada penurunan stres akademik siswa. Data hasil analisa ini dapat dilihat pada tabel dibawah, nilai $Z=-1,222$ dan taraf signifikansi lebih dari 0,005 yaitu 0, 111 .

Tabel 1.

Uji Mann Whitney gained Score pada Kelompok Eksperimen dan Kelompok Kontrol

\begin{tabular}{cccc}
\hline Pengukuran & $\mathbf{Z}$ & $\mathbf{P}$ & Keterangan \\
\hline Pretest-Posttest & $-1,222$ & 0,111 & Tidak terbukti \\
\hline
\end{tabular}

Lebih lanjut dapat dilihat bahwa rata-rata stres akademik siswa kelompok eksperimen dan kelompok kontrol mengalami kenaikan pada tabel 2 . 
Tabel 2. Rangkuman Mean Stress Akademik Siswa

\begin{tabular}{lll}
\hline Pengukuran & Kelompok & Mean \\
\hline Pretest & Eksperimen & 55.96 \\
& Kontrol & 53.19 \\
\hline Posttest & Eksperimen & 61.32 \\
& Kontrol & 57.33 \\
\hline
\end{tabular}

\section{PEMBAHASAN}

Tidak adanya pengaruh pelatihan dzikir terhadap penurunan stres akademik dan adanya temuan kenaikan rata-rata stress akademik pada pretest ke posttest disebabkan adanya peningkatan stressor akademik yang dihadapi siswa pada saat pemberian pelatihan dan sesudah pelatihan. Sesuai dengan pendapat (Wen, 2010) bahwa sebagian stres pada remaja berasal dari lingkungan sekolah salah satunya yakni tugas yang terlalu banyak, performansi akademik yang tidak memuaskan, persiapan untuk tes, kurangnya minat terhadap mata pelajaran/mata kuliah, dan hukuman dari guru. Harapan dari orang tua, guru dan diri sendiri biasanya menjadi sumber stres akademik.

penelitian di Yogyakarta juga menggambarkan tidak adanya pengaruh pelatihan dzikir terhadap penurunan stres mahasiswa. Keberhasilan intervensi stres melalui pelatihan dzikir dipengaruhi banyak faktor. Faktor internal inividu berkaitan dengan banyaknya tuntutan yang dialami oleh subyek penelitian. Misalnya tuntutan orang tua dan beban tugas yang dialami sehingga mempengaruhi kesiapannya menerima materi pelatihan dengan baik. sedangkan faktor eksternal dipengaruhi penguasaan trainer terhadap materi yang akan disampaikan. (Sucinindyasputeri dkk., 2017).

Hal lain yang mempengaruhi turunnya stress akademik adalah intensitas pemberian pelatihan dzikir. Pelatihan dzikir yang dilakukan secara rutin dalam jangka waktu tertentu mampu mendorong terbentuknya kebiasaan untuk berdzikir secara rutin. Hal ini didukung temuan Penelitian (Wulandari \& Huriyaty, 2015) bahwa dzikir dapat bermanfaat apabila dilakukan secara rutin sehingga pasien merasakan kedamaian dan ketenangan pikiran yang dapat mengurangi dampak hormon stres yang dilepaskan ketika cemas. Selain itu, treatmen menggunakan dzikir selama 6 minggu menunjukkan peningkatan persepsi stress dan keseimbangan hormon kortisol pada pasien(Amir, Mastutik, Taat Putra, \& Hasinuddin, 2018).

Secara teoritis perubahan pemikiran dapat mempengaruhi sikap seperti setuju, tidak setuju dan perasaan suka tidak suka. Tetapi belum tentu juga ketika seseorang menyukai sesuatu atau menyetujui sesuatu dia bisa melakukan perubahan langsung dalam perilakunya. Menurut (Azwar, 2010) sikap adalah unsur kepribadian yang harus dimiliki seseorang untuk menentukan tindakannya dan tingkah laku terhadap suatu objek disertai dengan perasaan postif dan negatif. Perasaan ini merupakan hasil proses analisis, penilaian, pertimbangan dengan pengetahuan yang telah ada di dalam otak sehingga mempengaruhi emosi seseorang dalam menentukan tindakan dan perilaku.Sehingga diperlukan waktu yang agak lama untuk proses pembiasaan.

Penelitian ini hanya mengukur pengaruh pelatihan dzikir pada memori jangka pendek. Pelaksanaan penelitian yang bertujuan untuk mengukur pengaruh pelatihan dzikir pada memori jangka panjang akan menambah pemahaman terhadap pengetahuan mengenai pengaruh 
pelatihan dzikir secara menyeluruh.

\section{KESIMPU \\ LAN}

Hasil penelitian ini menunjukkan tidak adanya pengaruh pelatihan dzikir dalam menurunkan tingkat stres akademik siswa di SMPN 2 Sine. Stres akademik siswa mengalami kenaikan dari pre test ke post test sesudah pelatihan dzikir. Hal ini menunjukkan indikasi bahwa stres akademik siswa bertambah karena semakin bertambahnya stressor akademik.

\section{DAFTAR PUSTAKA}

Ali, M. S., Ismail, M. S., Jusoh, W. H. W., Hadzrullathfi, S., Omar, S., \& Razak, R. A. (2018). Healing Stress Through Surah Al- Fatihah: An Alternative. 9(8), 6.

Amir, F., Mastutik, G., Taat Putra, S., \& Hasinuddin, M. (2018). Dhikr (Recitation) And Relaxation Improve Stress Perception And Reduce Blood Cortisol Level In Type 2 Diabetes Mellitus Patients With Oad. Folia Medica Indonesiana, 54. Https://Doi.Org/10.20473/Fmi.V54i4.10707

Azwar, S. (2010). Sikap Manusia Teori Dan Pengukurannya. Yogyakarta: Pustaka Pelajar.

Fischer, F. M., Radosevic-Vidacek, B., Koscec, A., Teixeira, L. R., Moreno, C. R. C., \& Lowden, A. (2008). Internal And External Time Conflicts In Adolescents: Sleep Characteristics And Interventions. Mind, Brain, And Education, 2(1), 17-23. Https://Doi.Org/10.1111/J.1751-228x.2008.00024.X

Hamid, A., Anwar, Z., \& Fasikhah, S. S. (2012). Metode Dzikir Untuk Mengurangi Stres Pada Wanita Single Parent. 10.

Kamil, M. (2012). Model Pendidikan Dan Pelatihan (Konsep Dan Aplikasi). Bandung: Alfabeta.

Lal, K. (2014). Academic Stress Among Adolescent In Relation To Intelligence And Demographic Factors. American International Journal Of Research In Humanities, Arts And Social Sciences, 5, 123-129.

Liem, A., Budiman Onggowijoyo, R., Santoso, E., Kurniastuti, I., \& Yuniarti, K. (2013, Agustus 21). Exploring Stressful Live Events On Indonesian Adolescents. Dipresentasikan Pada Proceedings Of The 10th Asian Association Of Social Psychology Biennial Conference.

Nist-Olejnik, S., \& Holschuh, J. (2016). College Rules! How To Study, Survive, And Succeed In College (Fourth Edition). Berkeley: Ten Speed Press.

Pascoe, M. C., Hetrick, S. E., \& Parker, A. G. (2019). The Impact Of Stress On Students In Secondary School And Higher Education. International Journal Of Adolescence And Youth, 1-9. Https://Doi.Org/10.1080/02673843.2019.1596823

Subandi, M. A. (2009). Psikologi Dzikir: Studi Fenomenologi Pengalaman Transfomasi 
Religius. Yogyakarta: Pustaka Pelajar.

Sucinindyasputeri, R., Mandala, C. I., Zaqiyatuddinni, A., \& Adityas, A. M. (2017). Pengaruh Terapi Zikir Terhadap Penurunan Stres Pada Mahasiswa Magister Profesi Psikologi. $8(1), 30-41$.

Wahyu Rochdiat, M., Hestu, E., \& Lestiawati, E. (2019). Dhikr As Nursing Intervention To Reduce Stress In Health Science Students. 4(1), 1-8.

Wahyuni, S., Anis, Soejoenoes, A., Putra, S. T., \& Syukur, M. A. (2018). Spiritual Dhikr Reduces Stress And Depression Symptom On Primigravidas. Pakistan Journal of Medical And Health Sciences, 12, 1368-1371.

Wulandari, I., \& Huriyaty, A. (2015). Anxiety's Level Of Bantenes Patient's: The Effect Of Dhikr Therapy Before Surgical Procedure. International Journal Of Research In Medical Sciences, 3, 36-40.

Yan, Y.-W., Rongmao, L., Su, Y.-K., \& Liu, M.-Y. (2018). The Relationship Between Adolescent Academic Stress And Sleep Quality: A Multiple Mediation Model. Social Behavior And Personality: An International Journal, 46, 63-77. Https://Doi.Org/10.2224/Sbp.6530

Yuwono, S. (2010). Mengelola Stres Dalam Perspektif Islam Dan Psikologi. Psycho Idea, 8(2), 14-26. 